\title{
ANALISIS KOMPARASI PENGGUNAAN PUPUK DAUN TERHADAP PRODUKTIVITAS DAN KEUNTUNGAN USAHATANI JAGUNG HIBRIDA
}

\author{
COMPARATIVE ANALYSIS OF LEAF FERTILIZER USE \\ ON PRODUCTIVITY AND ADVANTAGE OF CORN FARMING
}

\author{
Darmadji $^{1)}$, Akmad Masrukhin ${ }^{1)}$ and Suwarta ${ }^{1)}$ \\ ${ }^{1)}$ Fakultas Pertanian, Universitas Widyagama Malang \\ Email: darmaji@widyagama.ac.id
}

\begin{abstract}
ABSTRAK
Di Indonesia usahatani jagung hibrida memiliki prospek yang cukup bagus dilihat dari permintaan pasar nasional dan peluang ekspor yang dari tahun ke tahunnya terus meningkat. Salah satu cara untuk meningkatkan produktivitas dan keuntungan usaha tani jagung hibrida adalah memberi pupuk daun. Penelitian ini bertujuan untuk mengetahui produktivitas dan keuntungan usaha tani jagung hibrida yang menggunakan perlakuan dengan dan tanpa pupuk daun. Penelitian dilakukan di Desa Sladi Kecamatan Kejayan Kabupaten Pasuruan dengan mengambil data di satu petani di lahan yang sama dengan memberikan dua perlakuan yang berbeda, yaitu sebagian lahan menggunakan pupuk daun dan sebagian tanpa pupuk daun yang diambil dari 30 responden. Metode analisis komparasi yang digunakan adalah analisis independet $t$ test. Hasil penelitian menunjukkan ada perbedaan produktivitas rata- rata antara kedua perlakuan. Produktivitas yang menggunakan pupuk daun sebesar 7,7930/ha sedangkan yang tanpa pupuk daun sebesar 6,9217/ha. Selisih ratarata produktivitas kedua perlakuan 0.87133 ton/ha. Rata- rata keuntungan perlakuan yang menggunakan pupuk daun sebesar Rp. 11.751.226,8667 dan yang tanpa pupuk daun sebesar Rp. 8.773.850,9667/ha. Selisih rata-rata keuntungan kedua perlakuan sebesar Rp. 2.977.375,93/ha.
\end{abstract}

Kata Kunci: jagung hibrida, keuntungan, produktivitas, pupuk daun

\begin{abstract}
In Indonesia hybrid corn farming has a pretty good prospect in national market demand and export opportunities which is increased from year to year. One way to increase productivity and profitability of hybrid corn farming is by applying leaf fertilizer. This study aims to determine the productivity and benefits of hybrid corn farming using leaf fertilizer and those that not using it. This research was conducted in Sladi Village, Kejayan Subdistrict, Pasuruan Regency. The data was taken from one farmer on the same land with two different treatments. Part of land was given leaf fertilizer and the other part was not. The sample were taken from 30 farmers. The comparative analysis method used was independent $t$ test analysis. The results showed that there was difference in average productivity between two treatments. Productivity of the corn that using leaf fertilizer amounted to 7.7930/ha, while which not using it was $6.9217 /$ ha. The difference productivity between two treatments was 0.87133 tons/ha. The average profit using leaf fertilizer was Rp. 11,751,226.8667 and and that without it was Rp. 8,773,850,9667/ha. The difference average profit between two treatments was Rp. 2,977,375.93/ha.
\end{abstract}

Keywords: hybrid corn, leaf fertilizer, productivity, profit 


\section{PENDAHULUAN}

Di Indonesia dan juga di negeranegara ASEAN persoalan pangan menuju kemandirian juga menjadi topik yang aktual. Di lingkup negaraneraga ASEAN, skor ketahanan nasional mengalami kenaikan dibanding tahun sebelumnya namun skor ketahanan pangan tersebut masih kalah dibanding dengan negara-negara kawasan Asia Tenggara seperti Singapura, Thailand, dan Malaysia. Bahkan ketahanan pangan nasional di bawah Vietnam (Katadata_3, 2018). Oleh karena itu upaya peningkatan produksi semua komoditas pangan penting untuk terus ditingkatkan. Salah satunya adalah peningkatan produksi sekaligus peningkatan pendapatan usahatani jagung. Komoditas jagung menjadi kajian dalam penelitian ini karena merupakan salah satu komoditas yang memiliki peran yang sangat strategis.

Eksistensi komoditas ini tidak hanya sebagai sumber pangan tetapi juga sangat penting bagi aspek ekonomi yang lebih luas. Ditinjau dari aspek pangan, jagung merupakan sumber bahan pangan kedua yang bisa menggantikan beras. Di saat kebutuhan beras yang terus meningkat tidak bisa terpenuhi maka masyarakat bisa beralih ke jagung. Di sisi lain, peningkatan produksi jagung merupakan bagian integral dari upaya menuju kemandirian pangan.

Sebaliknya ditinjau dari aspek ekonomi, peningkatan produksi jagung tidak hanya indentik dengan upaya pendpatan petani tetapi juga menjadi sumber pendapatan bagi semua orang yang terlibat dalam usaha perjagungan mulai dari kegiatan ekonomi di sektor hulu hingga sektor hilir. Dari aspek ekonomi, komoditas jangung juga bisa menjadi sumber perolehan devisa (jagung memiliki potensi ekpor), sumber pertumbuhan ekonomi (melalui penciptaan output maupun penciptaan nilai tambah), sumber pajak dan sumber pendapatan pemerintah (berupa pajak baik yang dibayarkan petani maupun perusahaan). Di sisi lain, output produksi jagung bisa menjadi penggerak aktivitas ekonomi di sektor hulu sampai hilir. Di sektor hulu, aktivitas ekonomi jagung mendorong munculnya industri alsintan, industri pupuk dan obata-obatan, perbenihan dan industri pupuk. Sebaliknya di sektor hilir, aktivitas jagung merangsang tumbuhnya sektor industri 
makanan dan minuman yang berbasis jagung. Bahkan dari aspek sosial, aktivitas perjagungan menjadi peluang kesempatan kerja mulai dari kegiatan ekonomi di sektor hulu hingga di sektor hilir. Potensi komoditas jagung terhadap perekonomian, baik berkaitan dengan aspek pangan, pertumbuhan dan perdagangan juga dikemukakan oleh Antara (2009).

Berdasarkan data periode 1980-20016, produksi jagung menunjukkan tren yang terus meningkat, yaitu dari sekitar 5 juta ton pada tahun 1980-an menjadi 40 juta ton pada tahun 2016. Tren perkembangan produksi yang meningkat tersebut sejalan dengan meningkatnya luas areal tanam dari 1,1 juta ha pada tahun 1980 menjadi 5,5 juta ha pada tahun 2017 (Katadat_1, 2018).

Produksi jagung Indonesia tertinggi apabila dibandingkan di antara produksi Negara-negara ASEAN. Berdasarkan data ASEAN 2015, produksi jagung Indonesia mencapai 20,7 juta ton. Secara berturut-turut dari yang terendah adalah Kamboja (549,4 ribu ton), Laos (1,1 juta ton), Myanmar (1,7 juta ton),
Thailand (4,8 juta ton), Vietnam $(5,2$ juta ton) (katadata_2016).

Bahkan Pusat Data dan Sistem Informasi Pertanian (Pusdatin) Sekretariat Jenderal Kementerian Pertanian memproyeksikan neraca jagung hingga 2021 mencatat surplus. Produksi jagung tahun ini diprediksi akan mencapai 28,61 juta ton atau naik $2,35 \%$ dari tahun sebelumnya dan akan terus meningkat menjadi 32,65 juta ton pada 2021 (Katadata_2, 2018).

Ditjen TP juga menjelaskan bahwa perkiraan ketersediaan produksi jagung November sebesar 1,51 juta ton dengan luas panen 282.381 ha, sementara Desember 1,53 juta ton dengan luas panen 285.993 ha. Produksi ini tersebar di sentra produksi Jawa Timur, Jawa Tengah, Sumatera Utara, Sulawesi Utara, Sulawesi Barat, Gorontolo, Lampung, dan provinsi lainnya.

Sementara dari sisi kebutuhan, berdasarkan data dari Badan Ketahanan Pangan (BKP) Kementan, kebutuhan jagung tahun ini diperkirakan sebesar 15,5 juta ton PK, yang terdiri dari pakan ternak sebesar 7,76 juta ton PK, peternak mandiri 2,52 juta ton PK, untuk benih 120 ribu 
ton PK, dan industri pangan 4,76 juta ton PK. Artinya Indonesia masih surplus sebesar 12,98 juta ton PK, dan bahkan Indonesia telah ekspor jagung ke Filipina dan Malaysia sebanyak 372.990 ton.

Lebih lanjut menurutnya secara umum produksi jagung nasional saat ini sangat baik. Di wilayah Indonesia Barat panen terjadi pada JanuariMaret, atau mencakup $37 \%$ dari produksi nasional. Sedang di wilayah Indonesia Timur, panen cenderung mulai April-Mei. Sentra produksi jagung tersebar di 10 Provinsi yakni, Jatim, Jateng, Sulsel, Lampung, Sumut, NTB Jabar, Gorontalo, Sulut, dan Sumbar. Total produksinya sudah mencapai 24,24 juta ton $\mathrm{PK}$, artinya $83,8 \%$ produksi jagung berada di provinsi sentra tersebut berjalan dengan baik (CNBC, 2018). Namun persoalannya, meskipun produksi jagung dalam negeri terus meningkat bahkan menurut Mentan, Indonesia sudah ekspor ke Filiphina dan Malaysia sebesar 372.00 ton (Sindownews.com, 2018 dan Antaranews Jatim, 2018) dan juga surplus di tahun 2018 (Antaranews Jatim, 2018) faktanya Indonesia dari tahun ke tahun masih terus mengimpor jagung yang besarnya mencapai 1 juta ton. Demikian pula di tahun mendatang juga sudah direncanakan untuk impor jagung. Menurut Mentan, besarnya impor diperkirakan berkisar 50.000-100. 000 ton (CNBC, 2018).

Berdasarkan hal tersebut di atas, maka upaya peningkatan produksi jagung tetap menjadi persoalan aktual untuk diteliti. Demikian pula upaya peningkatan pendapatan bagi petani jagung, khususnya di Jawa Timur yang merupakan salah satu sentra jagung di Indonesia. Dengan harapan upaya peningkatan produksi di Jawa Timur dapat menjadi wacana peningkatan produksi jagung di sentra lainnya.

Secara nasional produk jagung tahun 2017 mencapai 27,95 juta ton. Jumlah itu tumbuh $18,55 \%$ dibanding tahun sebelumnya, dan mampu menghentikan impor produk jagung. Dari jumlah tersebut, jagung dari Jawa Timur memberi kontribusi terbanyak, yaitu 6,18 juta ton (Surya, 2018).

Di Jawa Timur budidaya tanaman jagung tersebar di 79 kota dan kabupaten. Berdasarkan data perkembangan produksi tahun 20072016, produksi jagung di Jawa Timur menunjukkan perkembangan yang 
meningkat dari 4.252.182 ton tahun 2007 menjadi 6.278.264 ton tahun 2016. Adapun tiga sentra produksinya di Kab. Tuban, Kab. Jember dan Kab. Lamongan (BPS Jatim, 2018).

Penelitian ini fokus pada upaya peningkatan produksi dan pendapatan usahatani jagung hibrida. Di Indonesia terdapat tiga jenis jagung selain hibrida yaitu jagung komposit dan jagung transgenik.

Jagung hibrida merupakan jagung yang proses pembuatannya dengan cara pemuliaan dan penyilangan antara jagung induk jantan dan betina untuk menghasilkan jenis baru. Jenis ini akan memiliki sifat keunggulan dari kedua induknya. Keunggulan jagung hibrida adalah kapasitas produksinya tinggi, mencapai sekitar 8-12 ton/ha. Namun varietas ini juga memiliki kekurangan, yaitu harganya mahal, dapat mencapai 20-40 kali lipat dari harga jagung konsumsi. Selain itu, jagung ini tidak bisa diturunkan lagi sebagai benih karena produksi akan turun mencapai $30 \%$, serta menimbulkan ketergantungan bagi petani karena jagung tidak bisa ditanam lagi.

Penelitian jagung hibrida dilaksanakan di Kab. Pasuruan Jawa
Timur berdasarkan pertimbangan Dirjen Prasarana dan Sarana Pangan (PSP) Kementan bahwa Kab. Pasuruan cocok untuk penanaman jagung hibrida. Terdapat 52 ha lahan yang dijadikan pilot project penanaman di PAsuruan. Dari 52 ha lahan yang ditanami jagung hibrida, 10 ha sudah dipanen. Salah satunya di Desa Sladi (Bangsa Online, 2017).

Meskipun jagung Hibrida memiliki keungulan dalam produksi, namun upaya peningkatan poduksinya penting untuk ditingkatkan. Berbagai upaya dilakukan untuk meningkatkan produksi dan produktivitas jagung. Mentan meluncurkan tiga program guna mendukung percepatan peningkatan produksi dan produktivitas, yaitu melalui: (a) Sekolah Lapangan Pengelolaan Tanaman Terpadu (SL-PTT), (b) Bantuan Langsung Benih Unggul non SL-PTT, dan (c) Cadangan Benih Nasional (CBN).

Program peningkatan SL-PTT sudah diterapkan oleh Balai Pengkajian Teknologi Pertanian Jambi. Penerapan program tersebut meningkatkan produksi antara 17,59$51,7 \%$ dibanding non SL-PTT (Adri dan Endrizal, 2011). 
Hayati dan Permadi (2016) meneliti peningkatan produksi jagung Hibrida berbasis Pengelolaan Tanaman Terpadu (PTT) dengan pemberian Mikroba Probiotik Lokal (MPL). Hasil penelitian menunjukkan bahwa MPL berpengaruh nyata pada pertumbuhan, komponen hasil dan hasil jagung hibrida P-21. Pipilan biji kering tertinggi dicapai pada pemberian mikroba probiotik lokal 6 1/ha Agri Simba $+3 \mathrm{~kg}$ Urea, yaitu sebesar 12,20 t/ha. Hasil terendah diperoleh dari pemberian 3 1/ha Agri Simba, yaitu 8,73 t/ha.

Upaya lain yang ditempuh oleh Balitserial untuk meningkatkan produksi Jagung adalah melalui penerapan IP 4.00 pada lahan kering. Konsep IP 4.00 ditujukan untuk memaksimalkan ruang dan waktu, sehingga indeks pertanian dapat ditingkatkan (Kabar Tani, 2018).

Adapun kebaruan dalam penelitian ini adalah peningkatan produksi dan produktivitas melalui penggunaan pupuk daun. Cara yang berbeda dibanding dengan ketiga cara yang dilakukan oleh peneliti sebelumnya. Permasalahan yang penelitian adalah apakah penggunaan pupuk daun dapat meningkatkan produktivitas dan pendapatan usahatani jagung. Adapun tujuan penelitian ini adalah untuk mengetahui dampak penggunaan pupuk daun terhadap peningkatan produktivitas hasil dan sekaligus pendapatan usahtani jagung. Untuk mencapai tujuan tersebut, maka penelitian ini membandingkan dengan produktivitas dan pendapatan usahatani jagung yang tidak menggunakan pupuk daun. Oleh karena itu, responden dalam penelitian ini terdiri dari dua kelompok yaitu petani jagung yang menggunakan pupuk dan yang tidak.

\section{METODE PENELITIAN}

\section{Penentuan Lokasi Penelitian}

Penelitian dilakukan di Desa Sladi, Kec. Kejayan, Kab. Pasuruan, Jawa Timur. Pemilihan lokasi didasarkan pada pernyataan Mentan bahwa kab. Pasuruan merupakan salah satu proyek percontohan penyebarluasan jagung hibrida di Jawa Timur. Desa Sladi adalah desa percontohan yang potensial.

\section{Metode Penelitian}

Berdasarkan tujuan penelitian, yaitu membandingkan produktivitas hasil dan pendapatan petani jagung antara yang menggunakan pupuk daun 
dan yang, digunakan metode stratified random sampling. Metode stratified menjadi dasar untuk membedakan dua kelompok responden yang berbeda, yaitu antara yang menggunakan pupuk daun dan yang tidak. Metode sampling menjadi dasar pengambilan sampel karena tidak semua petani jagung menjadi responden. Metode random menjadi dasar pengambilan sampel secara acak, di mana setiap orang berpeluang untuk terpilih sebagai responden.

\section{Metode Penentuan Jumlah Sampel}

Berdasarkana data Gapoktan 2018, jumlah petani jagung hibrida di Desa Sladi Kec. Kejayan Kab. Pasuruan sebanyak 150 petani, dengan rincian 103 petani tidak menggunakan pupuk daun dan 47 petani yang menggunakan pupuk daun. Dalam penelitian ini yang menjadi populasi adalah petani yang menggunakan pupuk daun dengan batas kesalahan $10 \%$. Rumus untuk menghitung jumlah sampel yang diambil adalah:

$$
\begin{aligned}
& \mathrm{n}=\frac{47}{1+47.10 \%^{2}} \\
& \mathrm{n}=\frac{47}{1+47.0 .01}=\frac{47}{1+0.47}=31,9
\end{aligned}
$$

Sampel dalam penelitian terdiri dua kelompok, yaitu responden petani jagung yang menggunakan pupuk daun dan yang tidak. Masing-masing kelompok responden berjumlah 30 orang.

\section{Metode Pengumpulan Data}

Data yang digunakan dalam penelitian ini adalah data primer dan sekunder. Sumber data primer adalah para petani yang saat penelitian dilakukan sudah memanen jagungnya, baik untuk petani jagung yang menggunakan pupuk daun maupun yang tidak. Metode penggalian data primer dilakukan melalui wawancara langsung dengan responden berdasarkan pertanyaan yang sudah disusun. Data yang digali dari responden di antaranya adalah karakteristik pribadi (nama, alamat, pendidikan), data input produksi (luas lahan, jumlah benih, pupuk, obat, tenaga kerja dan input lain baik kuantitas maupun harga per satuan input), data jumlah produksi dan harga jual.

Data sekunder dalam penelitian ini diperoleh dari pengurus Gapoktan, dan dari kantor desa tempat penelitian. Data sekunder yang dikumpulkan dari instasi Gapoktan meliputi jumlah petani jagung, jumlah input produksi (pupuk, benih dan obat), sedangkan 
data yang dikumpulkan dari kantor Desa Slidi antara lain data tentang kependudukan dan data administrasi.

\section{Metode Analisis Data}

Untuk mengetahui perbedaan produktivitas dan pendapatan usahatani jagung yang menggunakan pupuk daun dengan yang tidak, digunakan analisis komparasi antara dua kelompok responden tersebut. Alat analisis untuk uji komparasi antar dua perlakukan adalah analisis uji $\mathrm{t}$ test.

\section{Batasan Pengertian}

Batasan variabel yang digunakan dalam penelitian adalah: (1) produksi, yang dimaksudkan adalah produksi jagung dalam bentuk pipilan kering sawah yang dinyatakan dalam kuintal (kw) atau kilogram (kg), (2) produktivitas adalah produksi per satuan luas lahan yang dinyatakan dalam kw/ha, (3) biaya produksi adalah semua biaya yang dikeluarkan dalam proses produksi jagung, yang terdiri dari biaya tetap (penyusutan alat, pengairan dan pajak) dan biaya variabel (pupuk, pestisida, tenaga kerja, benih) yang dinyatakan dalam rupiah (Rp), dan (4) Keuntungan adalah sisa hasil penerimaan yang sudah dikurangi biaya yang dinyatakan dalam rupiah (Rp), (5) penerimaan adalah balas jasa dari hasil produksi yang sudah dirupiahkan atau hasil dari produksi jagung dengan harga jagung per kilogram, yang dinyatakan dalam rupiah ( $R p)$.

\section{HASIL DAN PEMBAHASAN}

\section{Deskripsi Responden}

Secara geografis Kabupaten Pasuruan berada di antara $112^{\circ}-113^{\circ}$ BT dan $7^{\circ} 32-7^{\circ} 57$ LS dengan luas $1474,015 \mathrm{~km}^{2}$. Desa Sladi merupakan salah satu desa yang termasuk di dalam wilayah Kecamatan Kejayan, Kabupaten Pasuruan. Dengan jarak dari Kota Kabupaten $\pm 10 \mathrm{~km}$ memudahkan penduduk mengakses informasi maupun memperoleh input usahatani maupun pemasaran produk pertanianya.

Dari data gapoktan Desa Sladi diketahui luas area sawah 90 ha dan pekarangan 10 ha. Oleh karena itu sektor pertanian sangat potensial dikembangkan. Desa Sladi merupakan salah satu daerah penghasil jagung yang cukup banyak di wilayah Kecamatan Kejayan Kabupaten Pasuruan, karena luas lahan pertanian memiliki proporsi yang besar, 
sehingga mendukung usahatani jagung.

Responden dalam penelitian ini adalah petani yang berusahatani jagung pada musim tanam tahun 2018. Setiap responden petani jagung di Desa Sladi memiliki karakteristik yang berbeda yang mempengaruhi keputusan petani jagung dalam menjalankan kegiatan usahataninya. Dalam penelitian ini karakteristik responden meliputi umur, luas lahan, status kepemilikan lahan, dan jumlah tanggungan keluarga. Karakteristik responden disajikan pada Tabel 1 .

Tabel 1. Karakterisitik Responden

\begin{tabular}{|c|c|c|c|}
\hline No & $\begin{array}{l}\text { Umur } \\
\text { ( Thn) }\end{array}$ & $\begin{array}{l}\text { Jumlah } \\
\text { Responden } \\
\text { (Orang) }\end{array}$ & $\begin{array}{l}\text { Persentase } \\
(\%)\end{array}$ \\
\hline 1 & $30-40$ & 8 & 26,67 \\
\hline 2 & $41-50$ & 15 & 50,00 \\
\hline 3 & $51-60$ & 5 & 16,67 \\
\hline \multirow[t]{2}{*}{4} & $61-70$ & 2 & 6,67 \\
\hline & Jumlah & 30 & 100,00 \\
\hline
\end{tabular}

Sumber: Data Primer (2018)

Berdasarkan pada Tabel 1 dapat diketahui bahwa bahwa sebagian besar petani jagung yang menjadi responden berada pada kelompok umur 41-50 tahun yaitu sebesar 15 orang atau $50,00 \%$ dari total responden. Sedangkan persentase terkecil pada

kelompok umur 61-70 tahun berjumlah 2 orang atau $6,67 \%$. Sebagian besar petani jagung responden di Desa Sladi berada pada kelompok umur produktif. Penduduk tergolong dalam umur produktif apabila kisaran umur 15-59 tahun di mana seseorang pada umur tersebut mempunyai pemikiran yang matang dalam menentukan keputusan terutama yang berhubungan dengan usahataninya.

Karakteristik kedua berdasarkan luas lahan. Distribusi luas lahan disajikan pada Tabel 2.

Tabel 2. Karakteristik Luas Lahan Responden

\begin{tabular}{cccc}
\hline No & $\begin{array}{c}\text { Luas Lahan } \\
(\text { ha })\end{array}$ & $\begin{array}{c}\text { Jumlah } \\
\text { (Orang) }\end{array}$ & Persentase (\%) \\
\hline 1 & $0,31-0,4$ & 4 & 13,33 \\
\hline 2 & $0,41-0,5$ & 6 & 20,00 \\
\hline 3 & $0,51-0,6$ & 2 & 6,67 \\
\hline 4 & $0,61-0,7$ & 4 & 13,33 \\
\hline 5 & $0,71-0,8$ & 7 & 23,33 \\
\hline 6 & $0,81-0,9$ & 7 & 23,33 \\
\hline & Jumlah & 30 & 100,00 \\
\hline Sumber : Data Primer $(2018)$ &
\end{tabular}

Berdasarkan data pada Tabel 2, jumlah responden didominasi oleh petani yang menggarap lahan seluas $0,71-0,9$ ha yaitu berjumlah 14 orang atau 46,66\%. Sedangkan jumlah responden paling sedikit adalah responden dengan luas lahan 0,51 - 
0,6 ha yaitu 2 orang atau hanya

$6,67 \%$. Jumlah tersebut menggambarkan bahwa sebagian besar petani di daerah penelitian merupakan petani yang memiliki luas lahan terbatas yakni kurang dari satu hektar. Meskipun demikian, usahatani jagung diharapkan dapat memberikan pendapatan yang maksimal.

\section{Hasil Analisis Uji Produktivitas}

Hasil uji independen sampel $\mathrm{t}$ test terhadap produktivitas disajikan pada Tabel 3. Hasil analisis menunjukkan uji komparasi produktivitas antara yang menggunakan pupuk daun dan yang tidak.

Tabel 3. Hasil Analisis Uji t-Produktivitas

\begin{tabular}{|c|c|c|c|c|c|c|c|c|c|c|}
\hline \multicolumn{11}{|c|}{ Independent Samples T Test } \\
\hline & & \multicolumn{2}{|c|}{$\begin{array}{l}\text { Levene's Test } \\
\text { for Equality } \\
\text { of Variances }\end{array}$} & \multicolumn{7}{|c|}{ t-test for Equality of Means } \\
\hline & & \multirow[t]{2}{*}{$\mathrm{F}$} & \multirow[t]{2}{*}{ Sig. } & \multirow[t]{2}{*}{$\mathrm{t}$} & \multirow[t]{2}{*}{$\mathrm{df}$} & \multirow{2}{*}{$\begin{array}{l}\text { Sig. } \\
(2- \\
\text { tailed } \\
\quad)\end{array}$} & \multirow[t]{2}{*}{$\begin{array}{l}\text { Mean } \\
\text { Differ } \\
\text { ence }\end{array}$} & \multirow{2}{*}{$\begin{array}{c}\text { Std. } \\
\text { Error } \\
\text { Differe } \\
\text { nce }\end{array}$} & \multicolumn{2}{|c|}{$\begin{array}{c}90 \% \text { Confidence } \\
\text { Interval of the } \\
\text { Difference }\end{array}$} \\
\hline & & & & & & & & & Lower & Upper \\
\hline \multirow{2}{*}{$\begin{array}{l}\text { Hasil } \\
\text { survey } \\
\text { pupuk }\end{array}$} & $\begin{array}{c}\text { Equal } \\
\text { variances } \\
\text { assumed } \\
\end{array}$ & 5,030 & 029 & 97,950 & 58 &, 000 & ,87133 & ,00890 & ,85646 &, 88620 \\
\hline & $\begin{array}{c}\text { Equal } \\
\text { variances } \\
\text { not } \\
\text { assumed }\end{array}$ & & & 97,950 & 47,900 &, 000 & ,87133 & 00890 &, 85641 &, 88625 \\
\hline
\end{tabular}

Sumber: Hasil Analisa Data (2018)

Berdasarkan Tabel 3 dapat diketahui mengenai hasil analisis perbedaan antara produktivitas jagung yang menggunakan pupuk daun dan yang tidak. Berdasarkan analisis, ratarata produktivitas jagung yang menggunakan pupuk daun sebesar 7,7930 ton/ha, sedangkan yang tidak menggunakan pupuk daun sebesar 6,9217 ton/ha atau selisih produkstivitas kedua perlakuan sebesar 0,87133 ton/ha.

Pada analisis ini toleransi taraf kepercayaan yang diguakan sebesar 90\%, sehingga dengan menggunakan taraf kepercayaan $90 \%$ rentang selisih produktivitas yang menggunakan pupuk daun dengan yang tidak adalahsebesar 0,85641 - 0,88625. 
Hasil Analisis Uji Pendapatan

Hasil analisis komparasi

pendapatan usahatani jagung antara yang menggunakan pupuk daun dan yang tidak disajikan pada Tabel 4.

Tabel 4. Hasil Analisis Uji t_Pendapatan

\begin{tabular}{|c|c|c|c|c|c|c|c|c|c|c|}
\hline \multicolumn{11}{|c|}{ Independent Samples Test } \\
\hline & & \multicolumn{2}{|c|}{$\begin{array}{c}\text { Levene's } \\
\text { Test for } \\
\text { Equality of } \\
\text { Variances }\end{array}$} & \multicolumn{7}{|c|}{ t-test for Equality of Means } \\
\hline & & \multirow[t]{2}{*}{ F } & \multirow[t]{2}{*}{ Sig. } & \multirow[t]{2}{*}{$\mathrm{t}$} & \multirow[t]{2}{*}{$\mathrm{df}$} & \multirow{2}{*}{$\begin{array}{l}\text { Sig. } \\
(2- \\
\text { taile } \\
\text { d) }\end{array}$} & \multirow[t]{2}{*}{ Mean Difference } & \multirow[t]{2}{*}{$\begin{array}{l}\text { Std. Error } \\
\text { Difference }\end{array}$} & \multicolumn{2}{|c|}{$\begin{array}{l}\text { 90\% Confidence Interval of the } \\
\text { Difference }\end{array}$} \\
\hline & & & & & & & & & Lower & Upper \\
\hline \multirow{2}{*}{$\begin{array}{l}\text { Hasil } \\
\text { survey } \\
\text { pupuk }\end{array}$} & $\begin{array}{l}\text { Equal } \\
\text { variances } \\
\text { assumed }\end{array}$ &, 218 & ,642 & 11,571 & 58 &, 000 & 2977375,90000 & 257316,60219 & 2547257,62278 & 3407494,17722 \\
\hline & $\begin{array}{l}\text { Equal } \\
\text { variances } \\
\text { not assumed }\end{array}$ & & & 11,571 & 57,744 &, 000 & 2977375,90000 & 257316,60219 & 2547226,70559 & 3407525,09441 \\
\hline
\end{tabular}

Sumber: Diolah dari Data Primer

Berdasarkan pada Tabel 4, dapat diketahui bahwa nilai Significance pada LTEV sebesar 0,642 sedangkan nilai $\alpha=0,5$. Hasil ini menunjukkan bahwa varians kedua pendapatan homogeny. Namun hasil uji t, menunjukkan nilai Sig 0.000. Hasil ini menunjukkan bahwa rata-rata pendapatan usahatani jagung yang menggunakan pupuk daun dan yang tidak adalah berbeda.

Berdasarkan hasil analisis, ratarata pendapatan usahatani jagung yang menggunakan pupuk daun sebesar Rp 11.751.226,8667, sedangkan yang tidak menggunakan pupuk daun sebesar Rp 8.773.850,9667.

\section{KESIMPULAN DAN SARAN}

\section{Kesimpulan}

Berdasarkan hasil analisis dan pembahasan dapat disimpulkan sebagai berikut :

1. Produktivitas usahatani jagung hibrida yang menggunakan pupuk daun $(7,7930$ ton/ha $)$ berbeda dengan yang tidak menggunakan pupuk daun $(6,9217$ ton/ha). Selisih keduanya sebesar 0,87133 ton/ha.

2. Keuntungan usahatani jagung hibrida yang menggunakan pupuk daun (Rp. 11.751.226,87) berbeda dengan keuntungan usahatani jagung yang tidak menggunakan pupuk daun (Rp 8.773.850,9667). 
Selisih keduanya sebesar Rp 2.977.375,900

\section{Saran}

Saran yang diberikan adalah seyogyanya petani di lokasi penelitian dianjurkan untuk menggunakan pupuk daun karena penggunaan pupuk daun dapat menghasilkan produktivitas dan pendapatan yang lebih tinggi, khususnya di Desa Sladi.

\section{DAFTAR PUSTAKA}

Adri dan Endrizal, 2011. Akselerasi Peningkatan Produksi dan Produktivitas Jagung Melalui SL-PTT Jgung Hibrida di Jambi. Naskah disampaikan pada Seminar Nasional. Pengkajian Teknologi Pertanian Jambi.

Antara. 2018. Kementan: Produksi Jagung Nasional Surplus pada 2018.

https://jatim.antaranews.com/ber ita/263735/kementan-produksijagung-nasional-surplus-pada2018. Antara news Jatim, Diakses November 2018.

Bangsa Online. 2017. Pasuruan Diproyeksikan jadi Sentra Lahan Jagung Hibrid. https://www.bangsaonline.com/b erita/33750/pasuruandiproyeksikan-jadi-sentra-lahanjagung-hibrida.

Diakses

November 2018

BPS Jatim. 2018. Produksi Jagung Menurut Kabupaten/Kota di Jawa Timur (Ton Tahun 2007-
2017).

https://jatim.bps.go.id/statictable /2018/10/29/1322/produksijagung-menurut-kabupaten-kotadi-jawa-timur-ton-2007-

2017.html. Diakses November 2018.

CNBC. 2018. Mentan Buka-bukaan Soal Alasan Impor Jagung di Tengah Surplus. https://www.cnbcindonesia.com/ news/20181108101744-4-

41177/mentan-buka-bukaansoal-alasan-impor-jagung-ditengah-surplus. CNBC Indonesia. Diakses November 2018

Hayati dan Permadi. 2016. Pengaruh Pemberian Mikroba Probiotik Lokal Terhadap Peningkatan Produksi Jagung Hibrida. Balai Pengkajian Teknologi Pertanian Jawa Barat.

Kabar Tani, 2018. Cara Cepat Meningkatkan Produksi Jaging. https://kabartani.com/cara-cepatmeningkatkan-produksijagung.html. Diakses November 2018.

Katadata, 2016. Produksi Jagung ASEAN 2015. https://databoks.katadata.co.id/d atapublish/2016/08/04/produksijagung-asean-2015. Diakses bulan November 2018

Katadata_1. 2018. Berapa Produksi Jagung Indonesia. https://databoks.katadata.co.id/d atapublish/2018/06/05/berapaproduksi-jagung-Indonesia. Diakses November 2018. 
Katadata_2. 2018. Produksi Jagung Diprediksi Surplus Hingga 2021. https://databoks.katadata.co.id/d atapublish/2018/10/10/produksijagung-diprediksi-surplushingga-2021. Diakses November 2018.

Katadata_3, 2018. Di ASEAN, Ketahanan Pangan Indonesia Di Bawah Vietnam. https://databoks.katadata.co.id/d atapublish/2018/11/02/di-aseanketahanan-pangan-indonesia-dibawah-vietnam. Diakses November 2018.

SindowNews, 2018. Kementan: RI Ekspor Jagung 372.000 Ton dan Stop Impor 9,2 Juta Ton. https://ekbis.sindonews.com/rea d/1352520/34/kementan-riekspor-jagung-372000-ton-danstop-impor-92-juta-ton-

1541557149. Diakses November 2018.

Surya. 2018. Pasar Benih Jagung Hibrida di Jatim Dorong Percepatan Kontribusi Lumbung Jagung

Nasional, http://surabaya.tribunn ews.com/2018/05/07/pasarbenih-jagung-hibrida-di-jatimdorong-percepatan-kontribusilumbung-jagung-nasional. Diakses November 2018. 